\title{
Exploring Small and Medium Enterprises' Perceptions Towards Islamic Banking Products in Morocco
}

\author{
Mustapha Ziky ${ }^{1} \&$ Raja Daouah ${ }^{2}$ \\ ${ }^{1}$ Faculty of Law, Economics and Social Science, Economics Department, Cadi Ayyad University, Marrakech, \\ Morocco \\ ${ }^{2}$ Cadi Ayyad University, Marrakech, Morocco and University of Basel, Switzerland \\ Correspondence: Raja Daouah, Faculty of Business and Economics, University of Basel, Peter Merian-Weg 6, \\ 4002 Basel, Switzerland. Tel: 417-6231-6143. E-mail: raja.daouah@gmail.com
}

Received: July 30, 2019

Accepted: August 16, 2019

Online Published: September 28, 2019

doi:10.5539/ijef.v11n10p106

URL: https://doi.org/10.5539/ijef.v11n10p106

\begin{abstract}
The main purpose of the study is to examine the willingness of Moroccan small and medium size enterprises to adopt Islamic finance methods and the factors that may affect their decision. The research method is based on a modified version of theory of planned behavior (TPB). A total of 250 questionnaires were randomly distributed to SME's managers but only 167 were valid for Analysis. The empirical findings based on our research framework indicate that most of SMEs are potential user of Islamic finance instruments. Noticeably, cost plays a major role in determining the likelihood of demand of these products by Moroccan SMEs. In addition, business support, risk sharing, suitability and self-efficacy were also found significant in determining the probability of use of Islamic financial methods by SME. The findings extend our understanding of Moroccan SMEs attitudes and awareness towards Islamic finance, and they are of key importance in informing future financial industry practice and financial policy formation in Morocco.
\end{abstract}

Keywords: Islamic finance, logistic regression, SME financing, intention, Theory of Planned Behavior

\section{Introduction}

Small and medium enterprises (SMEs) represent a significant part of the Moroccan economy. They represent more than $95 \%$ of the total number of operating companies, accounting for more than $30 \%$ of GDP and $48 \%$ of total employment. Debt is the most common solution for SMEs to meet their operational and investment needs (Badaj \& Radi, 2018). However, access to conventional debt requires tangible collateral and high interest rates, which are a major obstacles for Moroccan SMEs (Bengrich, 2006, Echatibi, 2010, Aabi, 2014).

According to the World Bank's survey (2007) (Note 1), the share of investment financed by banks was $12.2 \%$, while $75.4 \%$ of was financed internally. $31.6 \%$ of Moroccan companies surveyed identified access to finance as a major obstacle to their growth.

Furthermore, the SME market holds great potential for the development of participatory finance in Morocco. According to the report "participatory finance to SME" (2017) established by Finéopolis consulting, 32\% of small businesses in the MENA region are excluded from the banking system. The "non-conformity of the proposed products to Shariah" would be partly the cause. The results of the Thomson Reuters study published in 2014 support this explanation for the Moroccan case. This study indicates that almost half of Moroccan SMEs surveyed did not use any type of financial services in the past five years.

The policy makers are aware of the difficulties, that SME in Morocco face in order to access funding, the country has recently introduced Islamic finance to its financial system progressively and introduced a law regulating Islamic financial products and institutions. Therefore, this recent introduction of Islamic finance to the economy of the kingdom offers more financial options to SMEs, mainly two options: Mark-up products such as Murabaha and Profit and loss sharing products such as Musharakah and Mudarabah. These products would fulfill the Shariah obligation and provide the same value as conventional bank products (Rammal, 2004).

Most of the extent literature focuses on examining the perception and the attitude of consumers towards Islamic banking industry (Badaj \& Radi, 2018). However, just a few studies focus on the intention and the attitude of firms towards Islamic finance (Edris \& Almahmeed, 1997; Jalaluddin, 11999; Ahmad \& Haron, 2002; Osman \& 
Ali, 2008; Gait \& Worthington, 2009).

The present paper is an attempt to examine the SMEs' perception and acceptance of Islamic financing methods in Morocco. The aim is to examine what are the determinant that motivates these firms to adopt the Islamic financing instruments. We consider in this study the theory of planned behavior as a theoretical framework and logistic regression as the method of data analysis. Furthermore, the study has the following specific objectives:

- to inspect the perception of Moroccan SMEs towards Islamic financial services

- to examine the factors that motivates these firms to adopt Islamic banking services in Morocco

\section{Litterature Review}

Numerious previous studies have focused on attitude towards Islamic finance among individual customers. A very few efforts have been done to examine the attitude towards Islamic banking and finance from the perspective of business firms. The researchers who attempted to study business firms' attitude towards Islamic Banking were Edris (1997), Jalaluddin (1999), Ahmad and Haron (2002), Osman and Ali (2008) and Gait and Worthington $(2008,2009)$. Edris (1997) analyzed the determinants of bank selection in Kuwait by Business firms. He considered 304 business firms in a dual-banking system including both conventional and Islamic banking. His findings revealed that the majority of business firms prefer to deal with conventional banks than Islamic banks. This study indicates that although Islam being the dominated religion in Kuwait, and the religion factor in very significant in driving the individual customers' interest towards Islamic banking (Metwally, 1996), but it is not the major and the only determinant of bank selection for business firms in Kuwait.

Jalaluddin (1999) questioned three hundred and eighty-five small business firms in Australia about their attitudes towards the profit and loss sharing methods of finance. He indicates that there are other factors than religion for small business in Australia to use profit and loss sharing instruments such as business support, level of risk sharing between lenders and borrowers, risk default in the traditional system such as interest rates, the profitability linkages to the cost of borrowing and the expected rate of return. However, small business firms illustrate that they consider the expected rate of return and the degree of management intervention more important than religion while obtaining funds on profit and loss sharing basis.

In Malaysia, Ahmad and Haron (2002) studied the perception towards Islamic banking products and services among 45 corporate customers. The findings showed that there has been low usage of Islamic banking products. According to their analysis, the major finding was the economic factors such as profitability and quality of services were more significant for Malaysian corporate customers than religious reasons. They found that the majority of respondents $(65 \%)$ were non-Muslim who had low knowledge of Islamic banking principles and believe that Islamic banks have more suitable financial methods as an alternative to conventional finance methods.

Gait and Worthington (2008) who studies the attitudes of business firms towards Islamic financial products and services concluded that the predisposition to Islamic methods of finance is subsumed to the criteria taken in selecting a conventional bank. In another study, Gait and Worthington (2009) surveyed 296 Business firm in Libya on their intention and attitude towards Islamic banking. They have found that the majority of business firms in their sample (72.3\%) are interested to use Islamic finance services, and that the motivations behind this interest are profitability, Business support and unique services.

In Malaysia, Osman and Ali (2008) who surveyed Muslim entrepreneurs found that $80 \%$ of the total sample intent to use Islamic financing because of religious obligation or Shariah-based system. Other important reasons were certainty of the capital and the return. Among the users of Islamic financing (58\%), the motivating factors to use Islamic financing are the sense of belief that Islamic finance brings justice to people and it is more profitable than conventional financing. However, the non-user of Islamic banking and conventional one think there is no difference between the two systems, in fact, they consider Islamic financing more costly than conventional financing.

Other studies consider religious factors or Shariah-compliancy is crucial in driving Muslims towards Islamic banking (Haque, 2010). Al-Sultan (1999) considers that the major barrier to Islamic bank selection is the failure for the Islamic banking and finance to comply with Shariah-principle. Other studies have shown that there are other factors include image and reputation of the Islamic banks (Dusuki \& Abdullah, 2007) and cost benefits or profitability factors (Al-Ajmi, Hussain, \& Al-Saleh, 2009). Amin et al. (2014) consider a recommendation from friends and relatives could have a significant role in influencing customers' intention to use Islamic banking.

Recently, in North Africa, Ltifi et al. (2016) have studied the attitude of 180 Islamic bank clients in Tunisia and they found that costumers consider several factors while choosing an Islamic bank. Quality of service, trust, 
Sharia compliance are the most important factors in the selection of an Islamic bank. Furthermore, Aaminou and Aboulaich (2017) conducted a qualitative and quantitative study in order to model the behavior of consumers in a dual banking system. Theirs findings highlights that accessibility, Shariah compliance; pricing and service quality are the most significant factors influencing the choice Islamic banks in Morocco.

\section{Theoretical Framework and Hypotheses}

\subsection{Linking the Theory of Planned Behavior with SME's Financial Decision Making}

The first version of the theory of planned behavior was introduced by Fishbein and Ajzen (1975), the theory shows the effects of attitude, subjective norms and intentions on behavior. It was not until 1991, Ajzen modified the Theory of Reasoned Action into the theory of planned behavior. Other researchers (e.g. Godin \& Kok, 1996) argue that individual's self-control is not sufficient to explain behavior (Ajzen, 1988; 1991). Most of the behaviors lies between two extremes, which are total control, and lack of control totally (Godin, Valois, Lepage, \& Desharnais, 1992). In order to balance these observations, Ajzen (1985) added an additional determinant of intention, which is perceived behavioral control (PBC).

The theory of planned behavior is the most popular theory in explaining the behavioral intention of managers and owners of firms towards financial decision, in the extent literature, and outlines the key factors that influence their decisions (Souiden \& Rani, 2015; Ya'gobi \& Rad, 2015; Schlaegel \& Koenig, 2013). However, there is very little work done in the case of Morocco.

Although the model has empirically proved its validity, subsequent studies have shown the importance of modifying it to suit the particular research idea better (Taib et al., 2008; Ramayah et al., 2009). Other studies have suggested that adding variables related to religious beliefs and motivation would help improves the models' predictive ability (Godin \& Kok, 1996).

\subsection{Research Model and Hypothesis}

We adopt in this research paper the TPB as a theoretical framework for our study. We consider three groups of variables: attitude variables, subjective norm variables and perceived behavioral control variables. Following the extent literature, on one hand, the attitudinal variables are represented by cost, risk sharing, business support, service quality, difficulty to access conventional debt and financial suitability. On the other hand, the perceived behavioral control variables are represented by self-efficacy and facilitating conditions. As for subjective norms, we replaced it by religious norms, because Islamic finance is not well developed in morocco. The lack of experience could lead to unclear results in the case of subjective norms (Badaj \& Radi, 2018). Taken into account the chosen theoretical framework, we developed the following hypothesis:

\subsubsection{Cost}

Cost is one of the key factors influencing the SME's financial decisions (Gait \& Worthington, 2008). A study conducted by Ramayah et al. (2006) gives a clear verdict related to the inclusion of the perceived financial cost in the explanation of behavioral intention, and at the same time supports the conclusion of Amin et al. (2011) highlighting the importance of the perceived financial cost in Islamic banking transactions. Within the same context, it was found that the perceived financial cost negatively correlated with the intention to use Islamic financial products. The same conclusion can apparently be drawn from the studies of Yu (2012) and Luarn and Lin (2005). Therefore, the higher the perceived financial cost, the less likely it is to choose Islamic banking products. Therefore, we assume the following hypothesis:

\section{H1. Cost has a negative influence on the intention to use Islamic modes of financing.}

\subsubsection{Risk Sharing}

The entrepreneur in Mark-up or interest based contracts bears all the risk (Khan, 1995). In contrast, Islamic finance offers profit and loss sharing contracts, which is based essentially on risk sharing between the bank and the firm. This type of contracts encourages entrepreneurship and the SME supposed should prefer this kind of participatory financing (Khan, 1995). Consequently, we propose the following hypothesis:

H2. Risk sharing has a positive influence on the intention to use Islamic modes of financing.

\subsubsection{Business Support}

following the same logic of risk sharing, Islamic financial institutions offer business support to the firms funded through profit and loss sharing contracts (PLS), in order to support the interests of both parties (Khan, 1995). Business support is estimated to which extent Islamic banks supports the activities of firms in order to increase their growth, expansion, and competitiveness on the market (Gait \& Worthington, 2009). Therefore, we assume 
that the business support that comes with PLS instruments influence positively manager's attitude toward IFI:

H3. Business support has a positive influence on the intention to use Islamic modes of financing.

\subsubsection{Difficulty in Accessing Conventional Debt}

Numerous previous studies has shown that Moroccan SMEs face enormous difficulty in accessing conventional debt (Bengrich, 2006; Echatibi, 2010; Aabi, 2014). The access of Moroccan SMEs is restricted by many constraints such as high interest rates, collateral and long administrative procedures. The difficulty accessing conventional debt is explained by the fact that SME are fragile structures and therefore the bank requires more collateral and charge high interest rates in order to be protected against risk. The perceived difficulty in accessing conventional financing could affect the financing behavior and attitude of SMEs (Cressy \& Olofsson, 1997). In our study, we suppose that this difficulty could encourage SME to seek other financial sources such as Islamic finance.

\section{H4. Difficulty accessing conventional debt has a positive influence intention to use Islamic modes of financing.}

\subsubsection{Service Quality}

This variable has been widely studied in the bank marketing literature (McDougall \& Levesque, 2000; Taylor \& Baker, 1994). The competition between not only Islamic banks but also Islamic and conventional ones makes the service quality one of the determinant variables of theirs clients' attitude. Numerous studies have shown that quality is an important factor in adopting Islamic financial instruments (Aaminou \& Aboulaich, 2017; Awan \& Azhar, 2014; Eroll \& El-Bdour, 1989; Gerrard \& Cunningham, 1997; Haron et al., 1994; Ltifi et al., 2016).

H5. Service quality has a positive effect on the intention to use Islamic modes of financing.

\subsubsection{Suitability}

The search for financing is triggered by the need to cover financial requirements that may include diverging objectives as financing acquisitions, developing new products, customer segmentation or geographies, repaying loans, diversifying wealth or passing on the company (Poutziouris, 2001). In this study, suitability is measured by the extent to which Islamic modes of finance is appropriate to meet SMEs' financial requirement (Badaj \& Radi, 2018). Hence, we hypothesize that attitude should be positively affected by a higher perceived adequacy of Islamic financing instruments:

H6. Suitability of Islamic financial instruments to meet the financial requirements of the SME has a positive influence on the intention to use Islamic modes of financing.

\subsubsection{Religious Beliefs}

Religion is the one universal factor that affects people's attitudes and behavior (Arnould et al., 2004). Hence, it is a key factor in our study. Numerous studies on attitudes and intention towards Islamic banking products has shown that the values of people that are religious are different from non-religious people and it does affect strongly their financial decisions (Mokhlis, 2009; Rehman \& Shabbir, 2010). Following the previous studies, we suppose that religious beliefs has a significant effect on SMEs intention use of Islamic finance modes:

H7. Religious beliefs have a positive influence on the Moroccan SMEs' intention to use Islamic modes of financing.

\subsubsection{Self-Efficacy}

This variable is measured by the degree of knowledge and awareness of Islamic banking principals and products. Knowledge is defined as "the fact or the condition of knowing something with the familiarity obtained by experience or education" (Wirtz \& Mattila, 2003). Wahyuni (2012) conducted a study in Indonesia and found that knowledge of Islamic finance principals and products is an important factor in accepting Islamic banking. In addition, Sabirzyanov (2016) highlighted the positive correlation between the level of the client's knowledge of Islamic financial contracts and their willingness to deal with Islamic banks (Badaj \& Radi, 2018). Therefore, this study raises the following hypothesis:

\section{H8. Self-efficacy has a positive influence on the intention to use Islamic modes of financing.}

\subsubsection{Facilitating Conditions}

As indicated in the study conducted by Echchabi and Abd Aziz (2012), this variable is firmly connected to the socio-political, financial and economic state of the country. In the present research, we measure this variable in terms of to the presence of a well-established legal framework of Islamic financial segment in Morocco and the degree to which the Moroccan government promotes Islamic financial contracts. Hence, we suppose the 
following hypothesis:

H9. Facilitating conditions have a positive influence on the intention to use Islamic modes of financing.

\section{Research Methodology}

\subsection{Sample}

The data gathering was conducted by INREDD Laboratory at Cadi Ayyad University using primary data collection through personally administered questionnaires. Since the targeted population is the managers of SMEs in Morocco, we adopt as a unified definition of SMEs. The definition provided by the law governing these firms in Morocco. The Charter states that SMEs are "any business managed and/or administered directly by individuals who are shareholders, and is not owned by more than 25 per cent of capital or the voting rights by one enterprise or several enterprises, falling outside the SME definition".

SMEs occupy a prominent place in the national economy. They account for $40 \%$ of production and $31 \%$ of exports and operate in all sectors of economic activity. They account for $95 \%$ of Moroccan companies and about $50 \%$ of the private sector employment (Makhroute et al., 2013). With regard to private investment and overall added value, SMEs share accounts for 50\% and 20\% respectively. Moroccan SMEs are highly concentrated in commercial activities, which represent $41 \%$, and $37 \%$ are in the secondary sector (CDVM, 2015). In general, Moroccan SMEs are particularly distinguished by the following characteristics, such as the preponderance of the entrepreneur (ownerland manager), small size, weak supervision, low labor specialization, weakness of management practice, weak technology, lack of innovation and lack of clear and reliable information (Makhroute et al., 2013).

The technique of sampling used in this study was non-probability convenience sampling method. It was a viable alternative due to the constraint of time and the absence of a national database that we can take as reference. The final sample size is 167 .

\subsection{Questionnaire}

The survey used a structured questionnaire in French. It was designed to collect data on the perception of Moroccan SMEs regarding the attributes of Islamic finance services, as well as their intention to use them.

The questionnaire contains two main sections. The first part is meant to collect information about the characteristics of the SME and the demographic variables of the respondents, including gender, age, education level, etc. The second one is designed to collect information about the constructs of the theory of planned behavior. The items under this section are measured using binary scale.

\subsection{Logistic Regression for Analysis}

Logit and probit statistical analysis methods, also known as linear probability models, combine two types of statistical models, which are regression models and discriminant analysis (Draper \& Smith, 1998). They resemble to regression analysis in the way that they use independent variables to predict a dependent variable. The main difference is that in a regression, the dependent variable must be numerical, whereas in logit analysis and probit analysis, the dependent variable can be binary (categorical). Logit and probit analysis differ from discriminant analysis in the sense that they accept all types of independent variables (categorical and numerical) and the multivariate normality assumption is not necessary (Hagle \& Mitchell, 1992).

In order to overcome the limitations in the distributions of the dependent variable, binary logistic regression has been widely utilized. Generally, binary logistic regression depicts the relationship between binomially distributed dependent variable with its explanatory variables by taking the logarithm of both sides of equation. The dependent variable is denoted by $\mathrm{p}$, the probability of certain event happening.

In general, the logistic regression takes the form:

$$
\log \left[\frac{p}{1-p}\right]=\beta_{0}+\beta_{1} x_{1}+\beta_{2} x_{2}+\ldots+\beta_{n} x_{n}=x \beta
$$

Where $\mathrm{p}$ is the probability of the outcome of interest, $\beta_{0}$ is intercept term, $\beta_{1}$ is the coefficient associated with the corresponding dependent (explanatory) variable. The probability of the outcome of interest, $p$, is expressed as a non-linear function of the predictors in the form.

$$
p=\frac{1}{1+e^{-\left(\beta_{0}+\beta_{1} x_{1}+\beta_{2} x_{2}+\ldots+\beta_{n} x_{n}\right)}}
$$

The last equation ensures that the right hand side will always lead to values within the interval $[0,1]$. This called 
logistic response function.

In estimating a logit, we apply the Maximum Likelihood technique (MLT). One of the reasons why MLT is used is that MLT has a number of desirable large sample properties; MLT is unbiased and minimum variance for large samples (Studentmund, 2006). The binary logistic regression therefore avoids the problem that the linear probability model encounters in dealing with dummy dependent variables. Since real world data often described by not always having a linear pattern, this technique is quite satisfying for most researchers. For instance, in marketing, Akinci et al. (2007) indicates that logistic regression can generates more appropriate and correct findings in terms of model fit and correctness of the analysis.

In our study, the proposed empirical model can be postulated as follows:

$$
I N T_{i}=\beta_{0}+\beta_{1} x_{1}+\beta_{2} x_{2}+\ldots+\beta_{9} x_{9}
$$

INT is the dependent variable, which represent the intention to use the Islamic modes of finance by the Moroccan SME. If $\mathrm{INT}_{i}=1$ that means that the Moroccan SME intent to use the IF instrument and if $\mathrm{INT}_{i}=0$ this means that the Moroccan SME will not use the IF instrument.

\section{Results and Discussion}

\subsection{Descriptive Analysis}

Table 1. The main characteristics of the sample

\begin{tabular}{|c|c|c|}
\hline & Frequency & Percentage \\
\hline \multicolumn{3}{|l|}{ Professional status } \\
\hline Manufacturing & 7 & 4.2 \\
\hline Construction & 31 & 18.6 \\
\hline Trading & 61 & 36.5 \\
\hline Services & 50 & 29.9 \\
\hline Other & 18 & 10.8 \\
\hline \multicolumn{3}{|l|}{ Business Experience } \\
\hline Less de 1 year & 12 & 7.2 \\
\hline 1 to 5 years & 48 & 28.7 \\
\hline 6 à 10 years & 48 & 28.7 \\
\hline More than 10 years & 59 & 35.3 \\
\hline \multicolumn{3}{|l|}{ Capital } \\
\hline Less than 1 Million DH & 104 & 63.4 \\
\hline 1 to 20 Million DH & 48 & 29.3 \\
\hline 21 to 80 Million $\mathrm{DH}$ & 6 & 3.7 \\
\hline More than 80 Million DH & 6 & 3.7 \\
\hline \multicolumn{3}{|l|}{ Sales revenue } \\
\hline Less than 3 Million DH & 93 & 56.7 \\
\hline 3 to 175 Million DH & 58 & 35.4 \\
\hline More than 175 Million DH & 13 & 7.9 \\
\hline \multicolumn{3}{|l|}{ Number of employees } \\
\hline Less than 25 people & 115 & 68,9 \\
\hline 26 to 250 people & 42 & 25,1 \\
\hline More than 250 people & 10 & 6,0 \\
\hline \multicolumn{3}{|l|}{ Business type } \\
\hline Public limited company Limited liability & 18 & 11,2 \\
\hline company (SARL) & 137 & 85,1 \\
\hline Other & 6 & 3,7 \\
\hline \multicolumn{3}{|l|}{ Age of the respondent } \\
\hline $20-30$ & 30 & 18,1 \\
\hline $30-40$ & 52 & 31,3 \\
\hline $40-50$ & 42 & 25,3 \\
\hline $50-60$ & 33 & 19,9 \\
\hline plus de 60 & 9 & 4,8 \\
\hline \multicolumn{3}{|l|}{ Educational level of the respondent } \\
\hline Without & 8 & 4,8 \\
\hline Primary school & 13 & 7,9 \\
\hline Secondary school & 19 & 11,5 \\
\hline
\end{tabular}




\begin{tabular}{lcc}
\hline Higher education & 125 & 75,8 \\
Sex of the respondent & & \\
Male & 140 & 83.4 \\
Female & 27 & 16.6 \\
\hline
\end{tabular}

Table 1 shows the main characteristics of the sample in numbering and percentage for Moroccan SME. The sample is mostly constructed by SME operating in services (28.9\%) and in trading (36.5\%). More than the third (35.3\%) of the SME in our study have experience that exceeds 10 years and $57.4 \%$ of them have an experience between 1 - 5 years and 6 - 10 years. Over half of the respondents (63.4\%) have a capital less than 1 million DH and $29.3 \%$ of the respondents have a total asset between one and 20 million DH. The majority of respondents (68.9\%) have a number of employees less than 25. Most of the SME in our study are limited liability companies (SARL).

As for the demographic profile of the managers, from 167 respondents, which are included in the analysis, consisting of $83.4 \%$ male and $16.6 \%$ female. In addition, over of half of respondents $(56.6 \%)$ are in the age group of 30-40 and 40-50 years. Most of the respondents (75.8\%) hold a higher educational level and $11.5 \%$ of them have a secondary school level of education. Thus, this survey is believed to represent the educated respondent with good knowledge, good experience and high ability to understand Islamic finance methods.

\subsection{Reliability Measures}

Table 2. Reliability measure

\begin{tabular}{llc}
\hline & Variables & Cronbach's Alpha \\
\hline & Cost & 0.795 \\
& Risk sharing & 0.792 \\
Attitude & Business support & 0.790 \\
& Service quality & 0.794 \\
& Access to conventional debt & 0.803 \\
Religious beliefs & Financial Suitability & 0.806 \\
\multirow{2}{*}{ Perceived behavioural control } & Religious beliefs & 0.812 \\
& Self efficacy & 0.767 \\
\hline
\end{tabular}

Prior to hypothesis testing through logistic regression, it is important to check the reliability of the constructs. Cronbach alpha is the most widely used objective measure of reliability. This measure refers to the extent to which the items of the same construct measure the same concept (Vehkalahti, 2000), in other words, it measures the inter-relatedness of the items representing the same construct. The closer the Cronbach's alpha coefficient to 1.0 the greater the internal consistency of the items in the scale (Tavakol \& Dennick, 2011). According to Gliem (2003), the Cronbach alpha coefficient should be at least 0.6. The results shown in Table 2 indicate that all variables meet the threshold required, with Alpha values ranging from 0.767 to 0.812 . The results indicates that these items in this study have adequate reliability for the next stage of analysis.

\subsection{Logistic Regression}

Table 3. Classification table from logistic regression

Predicted

\begin{tabular}{llccc}
\multicolumn{1}{c}{ Observed } & \multicolumn{2}{c}{$\begin{array}{c}\text { Are you willing to use Islamic finance methods to } \\
\text { finance your investment? }\end{array}$} & No & Percentage correct \\
& & Yes & 15 & 96.8 \\
\hline Are you willing to use Islamic finance & Yes & 88 & 41 & 13.9 \\
methods to finance your investment? & No & 18 & & 79.6 \\
\hline Overall Percentage & & & 41 \\
\hline
\end{tabular}

The classification table indicates that the overall percentage is $79.6 \%$, which means that the logit model is quite accurate in predicting Moroccan SME intention to use Islamic modes of finance. The model chosen explains well the dependent variable. In $79.6 \%$ cases the dependent variable were correctly predicted given the model. In 
other words, the model successfully classified the use of Islamic methods of finance for $79.6 \%$.

Table 4. Results of logistic regression

\begin{tabular}{lcccc}
\hline Intention & B & S E & Sig. & Exp(B) \\
\hline Cost & $-1,537$ & 0.610 & 0.017 & 0.215 \\
Risk sharing & 1.556 & 0.508 & 0.002 & 4.740 \\
Service quality & 0.501 & 0.496 & 0.312 & 1.648 \\
Business Support & 1.893 & 0.538 & 0.000 & 6.641 \\
Access to conventional debt & -0.448 & 0.564 & 0.695 & 0.639 \\
Suitability & 1.492 & 0.542 & 0.006 & 4.445 \\
Self-Efficacy & 2.438 & 0.753 & 0.001 & 11.449 \\
Facilitating Conditions & 0.106 & 0.659 & 0.873 & 1.112 \\
Religious beliefs & 0.583 & 0.461 & 0.300 & 1.791 \\
Nagelkerke R & 0.624 & & & \\
Hosmer-Lemeshow (p-value) & 0.492 & & & \\
\hline
\end{tabular}

As shown in Table 5, the Hosmer-Lemeshow statistics is 0.492 , which is greater than 0.05 indicating there is no evidence of poor fit and the model adequately fits the data. In other words, the Hosmer-Lemshow tests fail to reject the null hypotheses of no functional misspecification. Therefore, it indicates that this model is appropriate for modeling the intention of use of Islamic finance by Moroccan SME (Hosmer \& Lemeshow, 2000). The Nagelkerke $\mathrm{R}^{2}$ statistic value is 0.624 illustrating that about $62 \%$ of the variation is explained by the logistic regression model.

The binary logistic regression analysis is then performed to identify influential factors, which are associated with the intention of Islamic banking adoption as the dependent variable. Backward elimination, a method of stepwise binary regression is used in the analysis because it will retain only the predictor variables that are statistically significant in the model (Menard, 12002). The regression results are shown in Table 4.

The coefficient for risk sharing is 1.556 , this implies that $\operatorname{Exp}(\beta)=\operatorname{Exp}(1.556) \approx 4.740$. A unit increase in risk sharing, ceteris paribus, will lead to the SME to be 4.740 more times likely to adopt Islamic banking products and services. Thus, a high value of risk sharing is associated with an increase in the adoption probability of Islamic banking schemes. The coefficient of business support is 1.893 , this implies that $\operatorname{Exp}(\beta)=\operatorname{Exp}(1.893) \approx$ 6.641. A unit increase in the factor business support, holding other variables constant, will lead to an increase of 6.641 times in the odds of respondents to adopt Islamic banking. Thus, a high value of business support is associated with an increase in Islamic banking adoption. The same goes for financial suitability and self-efficacy.

The coefficient of cost is -1.537 , this implies that $\operatorname{Exp}(\beta)=\operatorname{Exp}(-1.537) \approx 0.215$. Thus, a unit increases in the cost, will cause the probability of Moroccan SME to adopt Islamic banking to decrease by a factor of 0.215 , ceteris paribus. Thus, only cost, risk sharing, financial suitability, self-efficacy and business support are significant in predicting the probability of an increase (or decrease) in the potential use of Islamic banking products by Moroccan SMEs.

\subsection{Discussion}

Table 5. Summary of results

\begin{tabular}{|c|c|c|}
\hline Hypothesis & Sig. & Result \\
\hline H1. Cost has a negative influence on the intention to use Islamic modes of financing. & 0.017 & Supported \\
\hline H2. Risk sharing has a positive influence on the intention to use Islamic modes of financing. & 0.002 & Supported \\
\hline H3. Business support has a positive influence on intention to use Islamic modes of financing. & 0.000 & Supported \\
\hline H4. Access to conventional debt has a positive influence intention to use Islamic modes of financing. & 0.695 & Not Supported \\
\hline H5. Service quality has a positive effect on the intention to use Islamic modes of financing. & 0.312 & Not Supported \\
\hline $\begin{array}{l}\text { H6. Suitability of IF instruments to meet the financial requirements of the SME has a positive influence on } \\
\text { intention to use Islamic modes of financing. }\end{array}$ & 0.006 & Supported \\
\hline $\begin{array}{l}\text { H7. Religious beliefs have a positive influence on the Moroccan SMEs' intention to use Islamic modes of } \\
\text { financing. }\end{array}$ & 0.300 & Not Supported \\
\hline H8. Self-efficacy has a positive influence on the intention to use Islamic modes of financing. & 0.001 & Supported \\
\hline H9. Facilitating conditions have a positive influence on the intention to use Islamic modes of financing. & 0.873 & Not Supported \\
\hline
\end{tabular}


Hypothesis testing: According to the results summary presented in table 5, the results indicates that the cost has a significant negative effect on the intention of using Islamic modes of finance. The H1 is supported in our model. This results are in line with the finding of Jalaluddin (1999), Osman and Ali (2008). The findings provide a useful insight to bankers in order to develop a proper pricing strategy on the products. It thus justifies the need to look into this matter in the present study in the context of emerging market. In Addition, risk sharing has a significant influence on the SMEs' intentions to adopt IF services. Therefore, H2 is supported. This result is in line with the findings of Jalaluddin (1990).

Similarly, Business support has a significant effect on intention towards Islamic finance services, which support our initial hypothesis H3. Our results are in line with the findings of Jalaluddin (1999) and Gait and Worthington (2009) who demonstrated that business support is considered beneficial for enterprises. However, in many cases the managers do not appreciate the intervention of the bank in their management. The significance of the Business support and risk sharing could be attributed to the confidence of the SMEs towards Islamic financial institutions.

Financial Suitability has a positive and significant effect on the intention of SMEs' to adopt Islamic finance services. Hence, H6 is supported, which is in line with the proposition of Jalaluddin (1999) and (Gait \& Worthington, 2009). The Moroccan SME seem to perceive Islamic financial instrument are suitable to their financial requirement and needs.

The results show that self-efficacy has a significant influence on the intentional use of Islamic finance instruments. Hence, H8 is supported. The Moroccan SMEs confirm the need of knowledge about Islamic financial products, their structures, principals and functions. The more informed the SMEs, the more the probability of adopting Islamic financial services increases.

However, the results indicate that religious beliefs does not have significant negative influence on the attitude of Moroccan entrepreneurs towards PLS financing adoption. Thus, H7 is not supported. This is in which is in concordance with the findings of Amin et al. (2011), while it contradicts the findings of El Ouafy (2016) and Abourrig and Rachidi (2016). Furthermore, difficulty in accessing convention debt, service quality and facilitating condition were not significant. Hence, H4, H5 and H9 were not supported.

\section{Conclusion}

The main goal of the study was to examine the willingness of Moroccan SME to adopt Islamic banking services and to identify the variables that may influence their intention. The results showed that risk sharing, cost, financial suitability, business support and self-efficacy have a significant effect on the intention of use of Islamic modes of finance in Morocco by SMEs. On the other hand, religious beliefs, access to conventional debt, service quality and facilitating conditions do not have any influence on intention.

This study contributes in extending the literature investigating the attitudes towards Islamic finance, especially in SMEs context. It extends the range of beliefs variables and attitudes-intention variables simultaneously investigated as predictors in the Moroccan context. The current study examines the adoption of Islamic banking services by SMEs that are costumers and non-customers of Islamic banks in Morocco. Thus, it gives hindsight for practitioners and stakeholders on the Moroccan SME behaviour and attitude towards Islamic banking services, which should subsequently allow them to establish the necessary strategies to attract more SME and retain the existing ones. Over all, the findings extend our understanding of Moroccan SMEs attitudes and awareness towards Islamic finance, and provide remarkable implication for practice and policy.

Our study presents a number of limitations that must be considered in future research. First, the model we have proposed determines the use of the IF instruments for SME financing solely based on demand side considerations and does not explicitly explore the supply side arguments. Integrating supply-side variables into the analysis should improve the explanation of the observed financial behavior. Second, this study has limitations in sampling bias because it was difficult to obtain a truly representative sample. Therefore, the results cannot be generalized to all Moroccan SMEs. In addition, the variables and dimensions used in this study are not exhaustive. Hence, future studies have an interest in including other variables and dimensions to obtain results that are more complete.

\section{References}

Aaminou, M. W., \& Aboulaich, R. (2017). Modeling consumers' behaviour in new dual banking markets: The case of Morocco. Review of Pacific Basin Financial Markets and Policies, 20(2). https://doi.org/10.1142/S0219091517500096

Abdullah, A. A., Sidek, R., \& Adnan, A. A. (2012). Perception of non-Muslim customers towards Islamic banks 
in Malaysia. International Journal of Business and Social Science, 3(11), 151-163. Retrieved from https://www.semanticscholar.org/paper/Perception-of-Non-Muslims-Customers-towards-Islamic-AbdullahAbidin/8cbdc56d90e2db1c6f23fc8630502fb94faee2d4

Ahmad, N., \& Haron, S. (2002). Perceptions of Malaysian Corporate Customers Towards Islamic Banking Products and Services. International Journal of Islamic Finance Services, 3(1), 13-29. Retrieved from https://pdfs.semanticscholar.org/e831/c49041d1373db9431972449c5907c714ad5a.pdf?_ga=2.248065615.9 56658347.1568977113-995702341.1552035575

Ajzen, I. (1975). The Theory of Planned Behaviour. Organizational Behaviour and Human Decision Processes, 50, 179-211. https://doi.org/10.1016/0749-5978(91)90020-T

Ajzen, I. (2007). Attitudes, Personality and Behaviour (2nd ed.). New York : McGraw-Hill, USA.

Ajzen, I., \& Fishbein, M. (1988). Understanding Attitude and Predicting Social Behavior. Prentice-Hall, Englewood, Cliffs. NJ.

Akinci, S., Kaynak, E., Atilgan, E., \& Aksoy, S. (2007). Where does the logistic regression analysis stand in marketing literature? A comparison of the market positioning of prominent marketing journals. European Journal of Marketing, 41(5/6), 537-567. https://doi.org/10.1108/03090560710737598

Al-Ajmi, J., Hussain, H. A., \& Al-Saleh, N. (2009). Clients of conventional and Islamic banks in Bahrain: How they choose which bank to patronize. International Journal of Social Economics, 36(11), 1086-1112. https://doi.org/10.1108/03068290910992642

Al-Sultan, W. (1999). Financial characteristics of interest-free banks and conventional banks. Ph.D. Dissertations, the University of Wollongong.

Amin, H., Abdul Rahman, A. R., Sondoh Jr, S. L., \& Chooi Hwa, A. M. (2011). Determinants of customers' intention to use Islamic Personal Financing. Journal of Islamic Accounting And Business Research, 2(1), 22-42. https://doi.org/10.1108/17590811111129490

Badaj, F., \& Radi, B. (2018). Empirical investigation of SMEs' perceptions towards PLS financing in Morocco. International Journal of Islamic and Middle Eastern Finance and Management, 11(2), 250-273. https://doi.org/10.1108/IMEFM-05-2017-0133

Bengrich, M. (2006). Contribution à l'étude du comportement financier des petites et moyennes entreprises marocaines. PhD dissertation, Cadi Ayyad University, Morocco.

Conseil Déontologique des Valeurs Mobilières (CDVM). (2015). Rapport d'activité annuel 2014. Retrieved from http://www.cdvm.gov.ma/publications/rapport-annuel-du-cdvm-au-titre-de-lannee-2014

Cressy, R., \& Olofsson, C. (1997). The financial conditions for Swedish SMEs: Survey and research agenda. Small Business Economics, 9, 174-194. https://doi.org/10.1023/A:1007975924164

Draper, N. R., \& Smith, H. (1998). Applied Regression Analysis (3rd ed.). Wiley, New York. https://doi.org/10.1002/9781118625590

Dusuki, A. W. (2008). Understanding the objectives of Islamic banking: A survey of stakeholders' perspective. International Journal of Islamic and Middle Eastern Finance and Management, 1(2), 132-148. https://doi.org/10.1108/17538390810880982

Echatibi, M. (2010). Financement bancaire des PME au Maroc. PhD dissertation, Mohamed V-Agdal University, Morocco.

Echchabi, A., \& Abd Aziz, H. (2012). Empirical investigation of customers' perception and adoption towards Islamic banking services in Morocco. Oman Chapter of Arabian Journal of Business and Management Review, 1(10), 849-858. https://doi.org/10.12816/0002190

Edris, T. A., \& Almahmeed, M. A. (1997). Services considered important to business customers and determinants of bank selection in Kuwait: A segmentation analysis. International Journal of Bank Marketing, 15(4), 126-133. https://doi.org/10.1108/02652329710189393

El Ouafy, S. (2016). Contribution à l'étude des déterminants de l'intention d'utiliser les produits financiers islamiques: Cas des très petites entreprises marocaines. $\mathrm{PhD}$ dissertation, Ibn Zohr University, Morocco.

Gait, A., \& Worthington, A. (2009). An empirical survey of individual customer, business firms and financial institution attitudes towards Islamic methods of finance. International Journal of Social Economics, 35(11), 783-808. https://doi.org/10.1108/03068290810905423 
Gliem, J. A., \& Gliem, R. R. (2003). Calculating, interpreting and reporting Cronbach's Alpha reliability coefficient for likert-type scales. Midwest Research to Practice Conference in Adult, Continuing and Community Education. Ohio State University, Ohio.

Godin, G., \& Kok, G. (1996). The theory of planned behavior: A review of its applications in health-related behaviors. American Journal of Health Promotion, 11. https://doi.org/10.4278/0890-1171-11.2.87

Godin, G., Valois, P., Lepage, L., \& Desharnais, R. (1992). Predictors of smoking behaviour: An application of Ajzen's theory of planned behavior. British Journal of Addiction, 87, 1335-1343. https://doi.org/10.1111/j.1360-0443.1992.tb02742.x

Greene, W. H. (1990). Econometric Analysis. New York: Macmillan Publishing Company.

Hagle, T. M., \& Mitchell, G. E. (1992). Goodness-of-fit measures for probit and logit. American Journal of Political Science, 36(3), 762-784. https://doi.org/10.2307/2111590

Haque, A. (2010). Islamic banking in Malaysia: A study of attitudinal differences of Malaysian customers. European Journal of Economics, Finance and Administrative Sciences, (18), 7-18. Retrieved from https://pdfs.semanticscholar.org/665a/1b635b0ba84fbcba23eb23c0031f43a6d4e9.pdf

Jalaluddin, A. (1999). Attitudes of Small Business Firms and Financial Institutions Towards The Profit/Loss Sharing Method of Finance. PhD thesis, Australia.

Khan, T. (1995). Demand for and supply of mark-up and PLS funds in Islamic banking: Some alternative explanations. Islamic Economic Studies, 3(1), 39-78.

Koenig, M., Schlaegel, C., \& Gunkel, M. (2013). Entrepreneurial traits, entrepreneurial orientation, and innovation in the performance of owner-manager led firms: a meta-analysis (summary). Frontiers of Entrepreneurship Research, 33(4). https://doi.org/10.1111/j.1540-6520.2009.00308.x

Ltifi, M., Hikkerova, L., \& Gharbi, J. (2016). The determinants of the choice of Islamic banks in Tunisia. International Journal of Bank Marketing, 34(5). https://doi.org/10.1108/IJBM-11-2014-0170

Makhroute, M., Morsli, A., Tawafi, I., \& Rholam, Y. (2013). The issue of the definition of Moroccan SMEs and different approaches. Journal of US-China Public Administration, 10(5), 488-496.

Metawa, S., \& Almossawi, M. (1998). Banking behavior of Islamic bank customers: Perspectives and implications. International Journal of Bank Marketing, 16(7), 299-313. https://doi.org/10.1108/02652329810246028

Osman, M. R., \& Ali, H. (2008). Exploring Muslim Entrepreneurs' knowledge and usage of Islamic Financing. Seminar Keusahawanan Islam II Peringkat Kebangsaaan, Universiti Malaya.

Poutziouris, P. (2001). The views of family companies on venture capital: Empirical evidence from the UK small to medium-size enterprising economy. Family Business Review, 14(3), 277-291. https://doi.org/10.1111/j.1741-6248.2001.00277.x

Ramayah, T., Oh, S. M., \& Omar, A. (2008). Behavioral Determinants of Online Banking Adoption: Some Evidence from a Multicultural Society. Journal on Management, 2(3), 29-37. https://doi.org/10.26634/jmgt.2.3.335

Rammal, H. G. (2004). Financing through Musharaka: Principles and application. Business Quest. Retrieved from http://ssrn.com/abstract $=1442430$

Souiden, N., \& Rani, M. (2015). Consumer attitudes and purchase intentions toward Islamic banks: The influence of religiosity. International Journal of Bank Marketing, 33(2), 143-161. https://doi.org/10.1108/IJBM-10-2013-0115

Studenmund, A. H. (1992). Using econometrics: A practical guide. New York: Harper Collins.

Taib, T., Ramayah, \& Dzuljastri, A. (2008). Factors influencing intention to use diminishing partnership home financing. International Journal of Islamic and Middle Eastern Finance and Management, 1(3), 235-248. https://doi.org/10.1108/17538390810901168

Thomson Reuters. (2014). Morocco Islamic Finance 2014: Unlocking the Kingdom's Potential. Retrieved from http://www.cibafi.org/ControlPanel/Documents/Publication/PDF/MIFR2014.pdf

Travakol, M., \& Dennick, R. (2011). Making sense of Cronbach's Alpha. International Journal of Medical Education, (2), 53-55. https://doi.org/10.5116/ijme.4dfb.8dfd 
Vehkalahti, K. (2000). Reliability of measurement scales. The Finnish Statistical Society. Helsinki.

Williams, B., Brown, T., \& Osman, A., (2010). Exploratory factor analysis: A five-step guide for novices. Australian Journal of Paramedical, 8(3), 1-13. Retrieved from http://ro.ecu.edu.au/jephc/vol8/iss3/1

Wirtz, J., \& Mattila, A. (2003). The effects of consumer expertise on evoked set size and service loyalty. Journal of Services Marketing, 17(7). https://doi.org/17. 649-665. 10.1108/08876040310501223.

Ya'gobi, N. M., \& Rad, Z. N. (2015). Effective Behavioral Factors on Customers' Intention to Use Mobile Banking Services. A Journal of Economics and Management, 4(2), 128-143.

\section{Note}

Note 1. The survey targeted a large sample of SME and Banks.

\section{Copyrights}

Copyright for this article is retained by the author(s), with first publication rights granted to the journal.

This is an open-access article distributed under the terms and conditions of the Creative Commons Attribution license (http://creativecommons.org/licenses/by/4.0/). 